\title{
Article \\ Developing Knowledge of Supply Chain Resilience in Less-Developed Countries in the Pandemic Age
}

\author{
João M. Lopes ${ }^{1}\left(\mathbb{D}\right.$, Sofia Gomes ${ }^{2, *(D)}$ and Lassana Mané ${ }^{3}$
}

1 Miguel Torga Institute of Higher Education \& NECE-UBI-Research Unit in Business Sciences, University of Beira Interior, Estrada do Sineiro, s/n, 6200-209 Covilha, Portugal; joao.lopes.1987@hotmail.com 2 REMIT—Research on Economics, Management and Information Technologies, University Portucalense, R. Dr. António Bernardino de Almeida 541, 4200-072 Porto, Portugal

3 Miguel Torga Institute of Higher Education, Largo Cruz de Celas n1, 3000-132 Coimbra, Portugal; 880349@ismt.pt

* Correspondence: sofiag@upt.pt

check for updates

Citation: Lopes, J.M.; Gomes, S.; Mané, L. Developing Knowledge of Supply Chain Resilience in Less-Developed Countries in the Pandemic Age. Logistics 2022, 6, 3. https://doi.org/10.3390/ logistics6010003

Academic Editor: Robert Handfield

Received: 29 October 2021

Accepted: 27 December 2021

Published: 4 January 2022

Publisher's Note: MDPI stays neutral with regard to jurisdictional claims in published maps and institutional affiliations.

Copyright: (C) 2022 by the authors. Licensee MDPI, Basel, Switzerland. This article is an open access article distributed under the terms and conditions of the Creative Commons Attribution (CC BY) license (https:// creativecommons.org/licenses/by/ $4.0 /)$.

\begin{abstract}
Background: The constraints imposed by the pandemic COVID-19 increased the risks of the disruption of supply chains, bringing new challenges to companies. These effects were felt more intensely in less-developed countries, which are highly dependent on imports of products and raw materials. This study aims to assess the impact of supply chain resilience in a less-developed country (Guinea-Bissau) using complex adaptive system theory. Methods: We used a qualitative methodology through multiple case studies. Semi-structured interviews were conducted with four companies. The semi-structured script contains questions about supply chain disruptions, vulnerabilities and resilience. Results: The main results show that the companies in Guinea-Bissau, due to their dependence on the outside world and the absence of formal, larger and more diversified supply chains, suffered serious consequences with the disruption imposed by the pandemic. It was also concluded that the more resilient the supply chain, the fewer the impacts of crisis events and that the resilience of companies at this level depends on their obtaining competitive advantages over their competitors. Conclusions: The main practical implications of this study are the need to formalize the supply chain, diversify the supply of services and products of companies dependent on the exterior, adopt metrics that allow for the early detection of situations of supply chain disruption, effectively manage stocks and promote proactive crisis resolution strategies. Studies on the impact of resilience on supply chains in crises are scarce, especially on companies located in underdeveloped countries.
\end{abstract}

Keywords: logistics; resilience; strategies; complexity; operations management; SARS-CoV-2/COVID19 pandemic; supply chain vulnerability; supply chain disruptions

\section{Introduction}

Currently, supply chains in organizations are constantly challenged by risks, uncertainties and market vulnerability, threatening their performance. Thus, the level of interruption is high, causing a high range of consequences, including human and financial losses. Economic and/or natural interruptions (examples: terrorist attacks, diseases, fuel crises, political uncertainty and earthquakes, among other phenomena that affect the external environment) have become increasingly frequent, implying negative effects on supply chain operations. Disruption can arise in various forms, from the operational to the strategic level, including accidents or equipment failure, delays and obstacles in production, natural hazards and pandemics [1-6]. Thus, companies are increasingly looking for ways to adopt more reliable strategies for risk management in their supply chains. The goal is to manage the external or internal interruptions in the supply chain more effectively and consistently.

At this juncture, the recent COVID-19 pandemic caused many disruptions in the supply chain, and companies were faced with new problems such as: (1) the obligation to maintain physical and social distance, (2) mobility restrictions, (3) border closures, 
(4) labour and raw materials shortages, (5) the diversion of some raw materials for the manufacture of products considered of greater need in the fight against the COVID-19 pandemic (6) and also the exponential increase of certain demands for final products and raw materials $[7,8]$. As a result, companies had to adapt quickly to this new pandemic crisis scenario. This new scenario had not been properly anticipated in strategic planning, so companies had to take reactive actions to face it. One of the ways to combat this new scenario was for companies to become more resilient. Organizational resilience involves the ability to adapt to turbulent environments through routines that allow adequate and rapid responses to change $[9,10]$.

In this context, the supply chain is considered to be a dynamic and complex organism. The complexities of a supply chain arise mainly from its risk. Risks, as a rule, are caused by external factors beyond the control of managers and executives but do influence supply chains $[11,12]$. That said, the increasing uncertainty of the environment and the development of global supply chains require companies to adjust their standards in terms of logistics management. Companies, regardless of their environment, want to maintain continuity of supply in terms of material flows while optimizing cost reduction. Thus, companies want to build a resilient supply chain system to make it seamless $[13,14]$.

Supply chain resilience is defined as the capability to proactively design and plan the supply chain network, anticipating unexpected disruptive (negative) events in order to respond adaptively to disruptions. For a company to have resilience in its supply chain, it must maintain control of the entire logistics process. Usually, after the disruptive event, if the company is able to stay in the market, it becomes more competitive and may even gain a competitive advantage $[10,15]$.

On the other hand, the effects of the pandemic COVID-19 increased supply chain risks, bringing new challenges that are pertinent to be studied. The pandemic COVID-19 brought sudden instability in supply chains, which will impact the companies' results in the long term $[10,16]$. Companies' strategies in disruption situations can serve as a basis for other supply chain networks $[9,12,17,18]$.

Academics have studied supply chains over time [17-19]; however, these studies have been neglected for less-developed countries. In underdeveloped countries, disruptive situations that affect the value chain, such as COVID-19, can have severe and irreparable consequences in terms of supply, production and distribution and, as such, in terms of economic growth and development. Thus, it becomes pertinent to assess how creating more resilient and less vulnerable value chains in underdeveloped countries can allow companies to overcome disruptive situations and be drivers of value creation for companies.

Thus, the present context of this study is Guinea-Bissau, which is an underdeveloped West African country. Guinea-Bissau is currently considered the 16th poorest country in the world [20], which is the reason why it was chosen for the present study. Guinea-Bissau has a population of about 1.9 million [21]. The legal economy of Guinea-Bissau relies heavily on fishing and farming, and in recent years, cashew plantations have been increasing considerably. Guinea-Bissau is a recent example of political stabilization, which, together with the international community, plays a very important role in the context of cooperation and development [22]. According to Mendes [23], Guinea-Bissau's development is conditioned by economic growth through inefficiencies in production capacity, level of activity experienced, generation of civil servants and the country's level of indebtedness. According to data from AICEP [24], Guinea Bissau's trade balance in 2019 was in deficit by -86 million USD. Guinea-Bissau's exports were worth USD 249 million in 2019 and the five main groups of exported products were agricultural products $(66.2 \%$ of the total), wood and cork $(3.4 \%$ of the total $)$, minerals and ores $(1.5 \%$ of the total $)$, textiles $(0.4 \%$ of the total) and machinery and equipment ( $0.3 \%$ of the total). Imports amounted to USD 335 million in 2019 with the top five groups of imported products being agricultural products ( $20.8 \%$ of the total), food products $(18.4 \%$ of the total) and mineral fuels $(15.5 \%$ of the total), such as machinery and apparatus $(9.1 \%$ of the total) and common metals $(6.3 \%$ of the total). 
There is an urgent need to critically re-examine the development strategies that have been pursued in Guinea-Bissau and to adopt approaches that have real potential to put the country on the path of development [23]. The reversal of the trade balance can be a source of economic growth for Guinea-Bissau, a source that is very dependent on the value chain associated with the activities developed.

This study aims to analyze the influence of supply chain resilience in a less-developed country in West Africa using complex adaptive system theory (CAS) during the pandemic crisis. The unit of analysis is the companies that have their head office in Guinea-Bissau. Thus, the research questions are: What is the impact of the constraints caused by the COVID-19 pandemic on the value chain of companies in Guinea-Bissau that are dependent on the import of raw materials or final products? What is the impact of the constraints caused by the COVID-19 pandemic on the value chain of companies in Guinea-Bissau that are dependent on the export of raw materials or final products? Could it be that companies that have larger, more resilient value chains have a greater capacity to respond and adapt to this disruptive situation?

This study contributes to the literature on supply chain resilience in times of the pandemic crisis of COVID-19 in economically less-developed countries. Problems in supply chains in this country in the context of the COVID-19 pandemic are identified, suggesting possible measures to help companies overcome the issues identified.

As the main result, in all of the Guiné-Bissau companies studied, the pandemic had a negative impact on supply chains. None of the companies had the capacity to anticipate the disruptions caused by the pandemic COVID-19, as they were not previously prepared for a crisis. Companies were taken by surprise and were aggravated by the closure of borders, which resulted in delays in the arrival of products and raw materials, leading to stock-outs. Guinea-Bissau is an underdeveloped country in which very little is produced domestically. Most of the products and raw materials sold are imported, further accentuating the difficulties of local companies. With the closure of borders and the difficulty of transportation caused by the pandemic COVID-19, companies found it difficult to find other (domestic) solutions to supply their supply chains immediately. Thus, the supply chain drastically affected the economy, with direct impacts on companies' production due to delays in raw materials and marketing products by suppliers.

This study has the following structure: (1) it begins with the introduction to the topic addressed; (2) the literature review on the theory of complex adaptive systems, supply chain disruptions, supply chain vulnerability, supply chain resilience and the relationship between complex adaptive system and supply chain resilience) is elaborated; (3) the entire methodological process is detailed; (4) the results are exposed, and a discussion is carried out; (5) finally, the main conclusions arising from the study are described.

\section{Literature Review}

\subsection{Complex Adaptive System Theory (CAS)}

Complexity theory analyses change, whether it is renewal or adaptation. According to this perspective, organizations are considered complex adaptive systems. Thus, organizational change must consider the environment in which it operates [25-27]. Complex systems are made up of interacting parts at the micro-level. Changes at the macro level are often a consequence of small perturbations at the micro-level. In a complex system, the activities of various agents are very much linked to the actions of other agents in the system. Khanal et al. [25] state that the environment in which firms operate is constantly changing as they dynamically interact with the environment they influence while at the same time being influenced by the same environment. Thus, complex adaptive systems are composed of several independent agents that interact, adapt frequently, modifying and reorganizing their building blocks in light of prediction, experience and learning. Systems emerge over time, and it is often difficult to determine in advance the outcome of this emergence $[10,28]$.

Considering that there is no consensus on the definition of complexity theory, Preiser [29] and Preiser et al. [30], have identified six common underlying features that characterize 
and help understand complex adaptive systems. From a complex systems perspective, administrative replies to the COVID-19 pandemic can be conceptualized in six key features of a complex adaptive system: (1) Complex phenomena are relationally constituted; (2) Adaptive capacity to co-evolve and self-organize concerning contextual changes; (3) The dynamic relationships that characterize complex systems and their interaction are nonlinear; (4) Complex systems are context-dependent; (5) Complex systems are radically open systems; (6) Emergent phenomena appear as a result of complex causality.

Complex systems can have the capability to respond and adapt to the environment. Variation occurs at several scales, going from the micro to the macro level. The properties of resilience and adaptability possessed by complex systems allow them to change their internal structures and generate new behaviour patterns, requiring a selection perspective. In the case of organizational environments, this requires an understanding of emerging patterns and interventions that concentrate on standardizing products and processes or fitting the complexity of the environment [25,31].

The current literature on supply chain management considers supply networks as a system [32,33]. Tukamuhabwa et al. [34], recommend CAS as an appropriate lens for studying supply chain resilience. Thus, for the present study, we consider the supply networks in supply chain management as a "system", intending with this study to analyze the influence of supply chain resilience in a less-developed country.

\subsection{Interruptions and Vulnerability in the Supply Chain}

Firms increasingly rely on a complicated network of worldwide partners to provide services or products in the exact quantity, at the correct time and place, under persistent cost pressures [35-38]. Regrettably, complex and long supply chains are frequently slow in responding to change and are therefore vulnerable to disruptions of that supply chain. Chain disruptions are defined as unplanned and unforeseen events that interrupt the usual flow of materials and goods within a supply chain $[39,40]$. Based on this definition, these authors proposed five different sources of disruptions: (1) demand-side, (2) supply-side, (3) legal/regulatory, (4) infrastructure (5) and disasters. Although disruptions may have different sources and do not occur independently, all disruptions, in the end, will lead to one or more problems in the supply, distribution and demand of the product [41]. Both internal and external causes are at the root of supply chain disruptions.

Regarding external causes of supply chain disruptions, discussions mainly focus on severe events such as natural disasters and other "force majeure" events affecting the supply chain [42,43]. This is shown, for example, by Kondo [44], wherein the study is based on a powerful earthquake in Japan, or by Ferreira et al. [10], wherein the study is based on a pandemic. As for the internal causes of supply chain disruptions, Fartaj et al. [45], show that the transportation process and production logistics can be one of the main sources of supply chain process disruptions at the internal level in the automotive industry. However, disruptions not only arise from negative process deviations but can also be caused by positive innovation changes, as Beltagui et al. [46], show in the introduction of 3D printing processes in companies.

Currently, another phenomenon has emerged that has disrupted all markets and their chains, and in almost all their facets (demand side, supply side, legal/regulatory and infrastructure), the pandemic crisis. The COVID-19 pandemic and the measures for its containment served to create a new modus operandi for companies, leading to adaptations and choosing fewer long supply networks. The COVID-19 pandemic forced companies to invest in new technologies and open up more to the domestic market and markets they would never usually turn to. It also made managers realize that it is necessary to change how they organize and structure their business $[10,47,48]$.

Companies have become even more interdependent in an increasingly global market, where a material can be made in one country and assembled in a different one. As a result, companies need to create a wider network of relationships to mitigate the major vulnerability issues [49]. In this perspective, managers are aware of the risks that can influence the 
supply chain negatively, but managers have failed to implement the appropriate tools for managing these risks $[38,50,51]$. Supply chain risks are driven by a variety of internal and external sources of vulnerability. Moreover, Benedito et al. [52], distinguish between three broad categories of supply chain vulnerability sources: (1) endogenous assets (equipment, human resources, inventories, distribution, recovery and service centers); (2) supply chain partners (customers, suppliers and subcontractors); (3) and exogenous geographical factors (natural disasters, major accidents and intentional attacks).

In this context, the following proposition was formulated:

P1: The disruption in the value chain of companies in Guinea-Bissau caused by the COVID-19 pandemic, as it is an underdeveloped country, has not been overcome by the introduction of technological, organizational and logistical innovations.

\subsection{Supply Chain Resilience}

The COVID-19 pandemic had an impact never seen before on the global industry at all levels. Effective crisis management is needed to restore the links between socio-economic actors. However, beyond considering the negative effects of this type of historical crisis, this new scenario can be a source of opportunities to create beneficial change for the organization. The concept of resilience is incorporated into the management of organizations to guide this change. Alonso-Muñoz et al. [9] state that resilience is the ability of a company to adapt, reorganize its system and continue surviving and growing when a change is occurring, that is, while the disruption is happening. A resilient supply chain implies the ability of that chain to return normal operational performance, within an acceptable period, after being disrupted. The concept of resilience applied to supply chains refers to the need to mitigate and anticipate disruptions and disturbances along techniques tailored to decrease vulnerabilities in uncertain environments [10,53,54].

Operations in the supply chain are constantly changing and under conditions of uncertainty. Thus, resilience is a key factor [55]. Supply chains must be prepared to respond to unexpected events $[56,57]$. The main tenets of supply chain resilience are collaboration, supply chain reengineering, agility, innovation, flexibility, visibility, sharing and trust $[10,58]$. Researchers have advocated the importance of some factors to increase resilience in supply chains, highlighting integration, cooperation and communication. The ability to return more quickly to equilibrium after a period of disruption is called stability [9]. Complexity in supply chain networks, therefore, requires more resilience.

Complexity in supply chain networks plays a critical role in the adaptability of networks, interdependence, system-wide interactions and the ability to change their behaviour. Designing resilience, collaboration between suppliers and customers, agility and following a risk management culture are general principles of resilience in supply chain networks $[38,59,60]$. Logistics capabilities, such as low-cost distribution, reliability, speed of delivery and responsiveness for dynamic integration, enable supply chain resilience to become a competitive advantage. Resilience is a requirement for achieving sustainable development and thus, a transition to circular networks $[9,61]$.

In short, a company's resilience is the ability of the company to resume normal business and surrounding operations when some factor (internal or external) disrupts or interrupts its normal functioning. It becomes necessary to take quick and effective action the moment a disruption in this chain occurs. One important measure is to have an alternative plan in case the natural course of the business is interrupted. Such measures should be strategically planned well in advance so as not to catch managers off guard. A more resilient company is a company more likely to succeed.

In this context, the following proposition was formulated:

P2: In Guinea-Bissau, being an underdeveloped country, the value chain has low resilience to face disruptive situations. 


\subsection{Relationship between the Complex Adaptive System and Resilience in the Business Supply Chains}

The elements that make up a complex adaptive system are agents, autonomous actions, interaction and learning. These elements can be found within a supply chain network. Agents are firms or groups of firms that work together through partnerships or alliances in which they share rules and economic benefits. The companies create an environment of intense interaction motivated by exchanges of material, financial and informational resources. The search produces such exchanges for the achievement of the individual objectives of each company $[10,12,62]$.

For a long time, supply networks tended to adapt to their environment, i.e., shape their structures and add or exclude relationships between agents (e.g., connect with new suppliers and serve as new customers). In addition, these networks tended to change their physical capabilities and adapt behavioral processes, i.e., strategy changes [62]. In this way, the supply network interacts with environmental demands and modifies the environment for its competitors [32]. In this adaptation context, nonlinear effects may occur. In the face of continuous adaptations, a complex adaptive system may exhibit nonlinear and unpredictable effects. Therefore, the results are also irreversible. In a supply network, cost-reduction efforts by a large buyer may lead to random outcomes. However, a management goal might merge the control and autonomy of agents to improve the supply network [62-65].

In a supply network, its complexity, resilience and adaptation allow a complex resilient adaptive system to represent a business model more accurately than the general system theory, with strong alignment between the characterization of a complex resilient adaptive system and the characteristics of the business environment $[10,66]$. A business model is also a system of links between components and dynamics [67,68]. Thus, a business model includes a business system and a profitability model [69].

Thus, the following proposition was formulated:

P3: The business model of companies in Guinea-Bissau is not based on a complex resilient adaptive system that allows them to adapt to disruptive situations.

\section{Methodology}

This paper aims to analyze supply chain resilience in an underdeveloped West African country using complex adaptive system theory (CAS), that is, to assess the impact of a disruptive situation such as the COVID-19 pandemic on the value chain, determining companies' value chain vulnerabilities and the impact of value chain resilience to face these situations. This objective is in response to the demand for more empirical studies on supply chain resilience in less-developed countries. Supply chains in these countries have different characteristics and problems from more developed countries. In this study, we sought to understand why supply chains in less-developed countries at the time of the COVID-19 pandemic were susceptible to disruptions and which resilience strategies were adopted to reduce the impact of these disruptions. To achieve the proposed objectives, we used a qualitative methodology through multiple case studies.

The case-study methodology, through a multiple-case study, is the most appropriate for this study because it allows the observation in natural environments, as well as makes it possible to research and interpret specific phenomena, such as the functioning of supply chains, to understand the processes resulting from the activities of the companies under study [70-73]. This methodology has been increasingly adopted by academics, making it possible to deepen a given phenomenon [74-76]. This study's sampling type is not probabilistic by convenience because we only considered companies located in GuineaBissau. Only companies from Guinea-Bissau were selected because this country is one of the poorest countries in the world, and there is still a shortage of studies on this topic under analysis. For this study, we used a cross-analysis because the variables under study have characteristics that cannot be quantified [72,77]. Thus, given the small number of companies existing in Guinea Bissau and the selection of companies for the sample was 
based on convenience, a specific sector or dimension was not selected for the companies, the sample being constituted by companies with different characteristics. On the other hand, this fact also allows for more transversal conclusions, assessing whether the different characteristics of companies influence the way in which the value chain faces the disruptive situation caused by COVID-19.

Concerning the interviews, a semi-structured script previously applied by Ferreira et al. [10] and Yaroson et al. [12] was used. The semi-structured script was divided into four sections. The first section requested data about the company and the respondent. Section 2 contained the questions about supply chain disruptions, and Section 3 asked about supply chain vulnerabilities. In Section 4, we asked questions on supply chain resilience.

The data collection and processing process was elaborated upon, as shown in Figure 1.

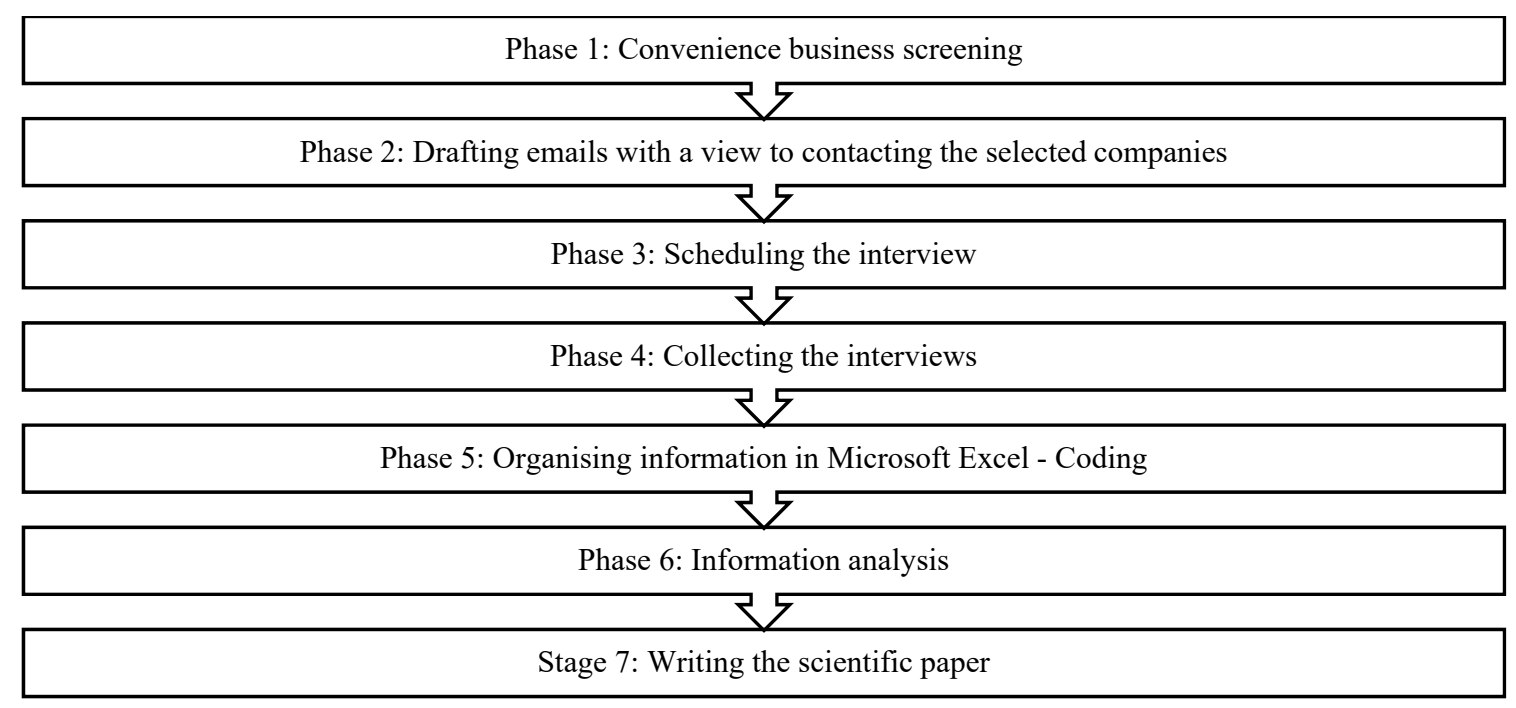

Figure 1. Process of data collection and processing.

The interviews were done with the CEOs of the companies because they are the ones who define the companies' strategies and, therefore, can provide more diverse, rich insights into the vulnerability and disruptions of their supply chains, as well as resilience strategies. The semi-structured interviews lasted an average of $60 \mathrm{~min}$. The interviews were collected in June and August 2021, and all companies are limited liability Corporations (Table 1).

Table 1. Companies' Dates.

\begin{tabular}{|c|c|c|c|c|}
\hline & Company A & Company B & Company C & Company D \\
\hline Date and Time of & 26 August 2021, at 5:30 & 8 June 2021 at 10:00 & 11 August 2021, at 4:00 & 25 June 2021 at 12:00 \\
\hline Interview & p.m. & a.m. & p.m. & noon \\
\hline Interviewee & CEO & $\mathrm{CEO}$ & CEO & $\mathrm{CEO}$ \\
\hline Type of Company & Limited Liability & Limited Liability & Limited Liability & Limited Liability \\
\hline 1ype of Company & Company & Company & Company & Company \\
\hline Area of Responsibility & $\begin{array}{l}\text { Construction and real } \\
\text { estate mediation. }\end{array}$ & $\begin{array}{l}\text { International moving } \\
\text { and logistics; archive } \\
\text { management. }\end{array}$ & $\begin{array}{l}\text { Maintenance, repair } \\
\text { and sale of generators. }\end{array}$ & Wood processing. \\
\hline $\begin{array}{l}\text { Years of Experience of } \\
\text { the interviewee }\end{array}$ & 4 years & 4 years & 25 years & 7 years \\
\hline Invoicing Volume 2020 & 100,000 Euros & 375,907 Euros & 500,000 Euros & 80,558 Euros \\
\hline
\end{tabular}

In Table 1, all companies belong to different activity sectors: Company $\mathrm{A}$ is dedicated to construction and real estate, Company $\mathrm{B}$ to international removals, logistics and archive management, Company $C$ to the maintenance, repair and sale of generators, and Company $\mathrm{D}$ to wood processing. Regarding the respondents' years of experience, the CEO of company 
A has been in this position for four years; the CEO of company $\mathrm{B}$ has also been in it for four years; the CEO of company $C$ has been in it for 25 years, and the CEO of company $\mathrm{D}$ has been in it for seven years. Regarding the turnover in 2020, company A invoiced 100,000 Euros; company B invoiced 375,907 Euros; company C invoiced 500,000 Euros, and company D invoiced 80,558 Euros, demonstrating the different sizes of the companies.

\section{Results and Discussion}

\subsection{Supply Chain Disruptions}

Supply chain disruptions are unplanned and unforeseen events that interrupt the normal flow of goods and materials within a supply chain $[39,40]$. Table 2 shows the results of supply chain disruptions. All firms revealed that delays in supplying products to consumers occurred at the onset of the pandemic in March 2020, although in GuineaBissau, the first cases of COVID-19 did not appear until nearly a month later, on March 25, 2020. For the most import-dependent companies, Companies A, B, and C, the delays took about 90 days, which was the period of border closure with the declaration of the state of emergency. In company D, the delay took about five days, related to the lack of materials in the domestic market and revealing their dependence on the domestic market. As identified by Bode et al. [39] and Wagner et al. [40], the source of interruption was initially at the infrastructure level, with the closure of borders that led to restrictions on the supply side, since companies faced difficulties in receiving raw materials from foreign suppliers. The interruption in the supply chain had negative effects that were all the greater because of the companies' dependence on longer networks outside Guinea-Bissau [10,47,48].

Table 2. Supply Chain Disruptions Results.

\begin{tabular}{|c|c|c|c|c|c|c|c|}
\hline Companies & $\begin{array}{l}\text { Timing of } \\
\text { Product Supply } \\
\text { Interruption }\end{array}$ & $\begin{array}{c}\text { Reason and } \\
\text { Duration for the } \\
\text { Delay }\end{array}$ & $\begin{array}{c}\text { The Speed of } \\
\text { the Perception } \\
\text { of the } \\
\text { Interruption }\end{array}$ & $\begin{array}{l}\text { Signal Metrics } \\
\text { in a Disruptive } \\
\text { Case }\end{array}$ & $\begin{array}{l}\text { Speedy Perception of } \\
\text { the Impact of the } \\
\text { Disruption }\end{array}$ & $\begin{array}{c}\text { Perceived } \\
\text { Impact on Areas } \\
\text { of the Supply } \\
\text { Chain }\end{array}$ & $\begin{array}{c}\text { Barrier } \\
\text { Encountered } \\
\text { during the } \\
\text { Interruption }\end{array}$ \\
\hline Company A & $\begin{array}{c}\text { Early March } \\
2020 \text { with the } \\
\text { declaration of a } \\
\text { state of } \\
\text { emergency. }\end{array}$ & $\begin{array}{l}\text { End of June; } \\
\text { closing of } \\
\text { borders. }\end{array}$ & $\begin{array}{l}\text { Since the } \\
\text { beginning of the } \\
\text { pandemic. }\end{array}$ & No & $\begin{array}{c}\text { It was a lengthy } \\
\text { process. }\end{array}$ & $\begin{array}{l}\text { Monthly reports } \\
\text { from production, } \\
\text { delivery and } \\
\text { service areas. }\end{array}$ & $\begin{array}{l}\text { Increased costs } \\
\text { of materials; lack } \\
\text { of human } \\
\text { resources. }\end{array}$ \\
\hline Company B & $\begin{array}{l}\text { At the start of } \\
\text { the pandemic, in } \\
\text { March } 2020 .\end{array}$ & $\begin{array}{l}3 \text { months, until } \\
\text { the end of June } \\
\text { 2020; closing of } \\
\text { borders. }\end{array}$ & $\begin{array}{c}\text { Being an } \\
\text { international } \\
\text { company, it was } \\
\text { able to anticipate } \\
\text { the situation } \\
\text { before the first } \\
\text { cases of } \\
\text { COVID-19 in } \\
\text { Guinea-Bissau. }\end{array}$ & No & $\begin{array}{l}\text { Two months before } \\
\text { COVID-19 arrived in } \\
\text { Guinea-Bissau, it had } \\
\text { already affected other } \\
\text { companies in the } \\
\text { group internationally. } \\
\text { There was daily } \\
\text { communication with } \\
\text { these companies to } \\
\text { anticipate the } \\
\text { interruption of } \\
\text { production. }\end{array}$ & $\begin{array}{l}\text { Monthly reports } \\
\text { of the sales and } \\
\text { expenses of each } \\
\text { business area. }\end{array}$ & $\begin{array}{c}\text { Rising costs of } \\
\text { materials and } \\
\text { import services; } \\
\text { greater } \\
\text { inefficiency in } \\
\text { public services } \\
\text { due to successive } \\
\text { strikes. }\end{array}$ \\
\hline Company C & $\begin{array}{l}\text { At the start of } \\
\text { the pandemic, in } \\
\text { March } 2020 .\end{array}$ & $\begin{array}{l}90 \text { days; closing } \\
\text { of borders. }\end{array}$ & $\begin{array}{l}\text { Since the } \\
\text { beginning of the } \\
\text { pandemic. }\end{array}$ & No & $\begin{array}{l}\text { Two months before } \\
\text { COVID-19 arrived in } \\
\text { Guinea-Bissau. }\end{array}$ & Monthly reports. & $\begin{array}{c}\text { There were few } \\
\text { barriers because } \\
\text { they had a large } \\
\text { stock of fuel for } \\
1 \text { year, already } \\
\text { foreseeing } \\
\text { possible delays } \\
\text { in materials } \\
\text { supply. }\end{array}$ \\
\hline Company D & $\begin{array}{l}\text { At the start of } \\
\text { the pandemic, in } \\
\text { March } 2020 .\end{array}$ & $\begin{array}{l}5 \text { days, due to } \\
\text { lack of materials } \\
\text { on the market. }\end{array}$ & $\begin{array}{l}\text { Since the } \\
\text { beginning of the } \\
\text { pandemic. }\end{array}$ & No & $\begin{array}{l}\text { Two months before } \\
\text { COVID-19 arrived in } \\
\text { Guinea-Bissau. }\end{array}$ & $\begin{array}{l}\text { Monthly reports } \\
\text { on production } \\
\text { and order } \\
\text { deliveries. }\end{array}$ & $\begin{array}{l}\text { Machine } \\
\text { breakdowns, } \\
\text { lack of parts in } \\
\text { the domestic } \\
\text { market and } \\
\text { delays in } \\
\text { receiving raw } \\
\text { materials. }\end{array}$ \\
\hline
\end{tabular}

The perception that the pandemic could lead to a disruption in the supply chain was detected from the beginning of the pandemic, although no company had metrics to detect warning signs of a disruptive event. The CEOs of these firms are concerned that risk 
situations, such as this pandemic crisis, can have harmful and irreversible consequences on their supply chain. Company $\mathrm{C}$ indicates that "There are no metrics available. We only took into account information from the news and social media". Still, Tang [50] and Tang [51] argued that they have delayed and failed to implement alerts, namely management control systems based on business metrics that adequately manage this type of risk.

The monthly reports prepared by the companies in terms of production, sales, services and orders allowed the detection of the areas that would be most affected. Company D states that "the company evaluates through analysis of production levels and order delivery response". Still, they were already in a reactive strategic phase, i.e., companies had to change their strategy in reaction to the disruption already existing in their supply chain. The supply in the domestic market and the investment in new technologies can be a solution to minimize the impacts of the pandemic crisis in the business investment chain $[10,47,48]$.

Finally, according to the interviewed CEOs, the recovery from the supply chain interruption was affected by several barriers such as rising raw material costs, lack of human resources, higher import costs and the inefficiency of public services (customs and finance, for example) due to numerous strikes. Company B stated that there was an "Increase in the price of import materials and services. Greater inefficiency of public services in terms of finance, customs and port services, even after the end of the confinement due to successive strikes". However, the company D revealed not to have felt many barriers because they had a large stock of fuel for 1 year, already foreseeing possible delays in the supply of materials, pointing to the breakdown of machines, lack of parts in the domestic market and the delay in receiving raw materials as the main obstacles. The barriers to the supply chain replenishment identified by companies $\mathrm{A}, \mathrm{B}$ and $\mathrm{C}$ demonstrate that companies, as the market is so global and susceptible to different internal and external risks, should create more extensive and diversified networks of relationships [50,51].

\subsection{Supply Chain Vulnerabilities}

Table 3 shows the results of the responses of the CEOs of the interviewed companies regarding supply chain vulnerabilities. Concerning the type of characteristics that the companies produce or provide services, the interviewed companies, as shown in Table 1, have different branches of activity: construction and real estate (Company A), international moving services, logistics and archive management (Company B); maintenance, repair and sale of generators (Company C); and wood processing (Company D). Because the products and services provided are distinct, the effect of a supply chain disruptive activity has different impacts. In the case of companies $A, C$ and D, since they are industries, i.e., producers of goods, in the event of disruptive activity, they are left without access to raw materials and, as such, the production can stop, with the source of the disruptive activity being the supply side, as identified by Bode et al. [39] and Wagner et al. [40]. Company B is a service provider company and, in the event of disruptive activity in the normal supply chain, it more easily seeks an alternative to maintain the quality of the transport process, the transport process and logistics being one of the main sources of disruptions in the supply chain process [45].

Given the nature of the company's activity, the supply chains of companies A, C and $\mathrm{D}$ consist of purchasing raw materials from suppliers, their transformation and/or incorporation into the final product and then the sale to the end customer. In company B, the client delivers the goods to be distributed to the company, which will store them and then distribute them, usually by sea. Once customs clear the goods, they are delivered to the final client of the company that contracted the service to company B. All the companies mentioned that the resources required for their operations do not increase the impact of disruptive activities. 
Table 3. Supply Chain Vulnerabilities Results.

\begin{tabular}{|c|c|c|c|c|c|c|}
\hline Companies & $\begin{array}{l}\text { Product Attributes } \\
\text {-Whether it Increases } \\
\text { Disruptive Activity }\end{array}$ & Supply Chain & $\begin{array}{l}\text { Amplifier } \\
\text { Feature for } \\
\text { Disruptive } \\
\text { Events }\end{array}$ & $\begin{array}{l}\text { Position of } \\
\text { Suppliers in } \\
\text { Disruptive } \\
\text { Events }\end{array}$ & $\begin{array}{c}\text { Role of } \\
\text { Suppliers }\end{array}$ & $\begin{array}{l}\text { Influence of } \\
\text { Management } \\
\text { Decisions during } \\
\text { a Disruption }\end{array}$ \\
\hline Company A & $\begin{array}{l}\text { In the case of } \\
\text { construction, } \\
\text { products are durable } \\
\text { and require many raw } \\
\text { materials, which is the } \\
\text { factor most affected } \\
\text { by a disruption. }\end{array}$ & $\begin{array}{l}\text { Raw materials are } \\
\text { mainly purchased } \\
\text { domestically, } \\
\text { with some more } \\
\text { specific products } \\
\text { having to be } \\
\text { imported. }\end{array}$ & No. & $\begin{array}{l}\text { The supplier } \\
\text { must understand } \\
\text { the way of } \\
\text { working, the } \\
\text { deadlines and } \\
\text { quantities } \\
\text { practiced, } \\
\text { delivery methods, } \\
\text { etc. }\end{array}$ & $\begin{array}{l}\text { The suppliers } \\
\text { anticipate the } \\
\text { rupture or lack of } \\
\text { certain raw } \\
\text { materials and so } \\
\text { that we can find } \\
\text { an alternative } \\
\text { solution if that } \\
\text { raw material is } \\
\text { needed. }\end{array}$ & It doesn't exist. \\
\hline Company B & $\begin{array}{l}\text { Packaging material } \\
\text { must be of quality } \\
\text { and specialized. } \\
\text { There must be access } \\
\text { to a global network } \\
\text { with reliable and } \\
\text { internationally } \\
\text { accredited partners in } \\
\text { countries with no } \\
\text { company } \\
\text { representation. Little } \\
\text { affected by disruptive } \\
\text { activities (transport } \\
\text { processes used would } \\
\text { have to remain the } \\
\text { same, and the } \\
\text { company would } \\
\text { easily adapt to new } \\
\text { transport processes). }\end{array}$ & $\begin{array}{l}\text { They leave the } \\
\text { main customer, } \\
\text { then are stored in } \\
\text { the company and } \\
\text { subsequently } \\
\text { distributed. After } \\
\text { arrival at } \\
\text { destination } \\
\text { (usually by } \\
\text { sea)-and cleared } \\
\text { by customs and } \\
\text { stocked, and } \\
\text { reaches the final } \\
\text { consumer } \\
\text { through direct } \\
\text { sale of the } \\
\text { material or local } \\
\text { transport } \\
\text { services. }\end{array}$ & No. & $\begin{array}{l}\text { Suppliers are very } \\
\text { important in the } \\
\text { supply chain } \\
\text { because it is not } \\
\text { possible to arrive } \\
\text { with the product } \\
\text { to its destination. }\end{array}$ & $\begin{array}{l}\text { Suppliers are } \\
\text { always in contact } \\
\text { with the company, } \\
\text { indicating any } \\
\text { problems that } \\
\text { may arise. }\end{array}$ & It doesn't exist. \\
\hline Company C & $\begin{array}{l}\text { Filters and subsalient } \\
\text { parts for long-lasting } \\
\text { engines and therefore } \\
\text { depend on the } \\
\text { maintenance of a } \\
\text { supply chain depend } \\
\text { on the supply of these } \\
\text { parts. }\end{array}$ & European market. & No. & $\begin{array}{l}\text { Suppliers are very } \\
\text { important in the } \\
\text { supply chain } \\
\text { because, without } \\
\text { them, the } \\
\text { business stops. }\end{array}$ & $\begin{array}{l}\text { There is a close } \\
\text { relationship with } \\
\text { suppliers so that } \\
\text { the company } \\
\text { always gets the } \\
\text { materials it needs. }\end{array}$ & $\begin{array}{l}\text { The stock of } \\
\text { consumables } \\
\text { already in place } \\
\text { allowed the } \\
\text { company to have } \\
\text { no difficulties. }\end{array}$ \\
\hline Company D & $\begin{array}{l}\text { Furniture is } \\
\text { dependent on many } \\
\text { raw materials and } \\
\text { customer purchasing } \\
\text { power. Raw material } \\
\text { dependence and } \\
\text { customer demand } \\
\text { amplify disruptive } \\
\text { effects. }\end{array}$ & $\begin{array}{l}\text { Raw materials are } \\
\text { ordered from } \\
\text { suppliers used to } \\
\text { produce the } \\
\text { furniture and } \\
\text { then sold to } \\
\text { customers. }\end{array}$ & No & $\begin{array}{l}\text { Suppliers inform } \\
\text { us in advance } \\
\text { when there is a } \\
\text { change/alteration } \\
\text { in their products } \\
\text { and so that we } \\
\text { can adjust } \\
\text { production. }\end{array}$ & $\begin{array}{l}\text { Yes, the suppliers } \\
\text { contact the } \\
\text { company to } \\
\text { understand the } \\
\text { need for some } \\
\text { raw materials. }\end{array}$ & $\begin{array}{l}\text { Decisions at the } \\
\text { supply chain } \\
\text { level are taken by } \\
\text { the partners, and } \\
\text { in case of } \\
\text { disruption, the } \\
\text { partners look for } \\
\text { new alternatives. }\end{array}$ \\
\hline
\end{tabular}

Suppliers are generally recognized as having an important role in the supply chain disruption, as mentioned by Bode et al. [39], Wagner et al. [40] and Benedito et al. [52]. On the one hand, because they understand the way the company works, the deadlines and the necessary quantities of raw materials that the company needs (Company A) ensure that the products arrive at their destination in the agreed times (Company B) and help adjust the company's production in case of changes in its supplied products (Company D). Company D states that "suppliers inform the company in advance when there is a change/change in any of the products". In this way, the relationship with suppliers is valued, believing that they play an important role in the supply chain's vulnerability [10].

Regarding the company's management decisions in cases of disruptive activity, companies $\mathrm{A}$ and $\mathrm{B}$ refer that there is not one. However, company $\mathrm{C}$ mentions that the management decision to have consumable stocks has already allowed anticipating disruptions 
in supply chains. Company C states that "we have a one-year stock of consumables. This allowed us to face this time of pandemic with some carelessness about the stock". The CEO of company D notes that the company's management plays an important role in the search for alternatives when these episodes occur. Company D indicates that "supply management decisions are outlined between the partners, in case there is an interruption that exceeds the availability that the company has, the partners enter with refundable amounts for this purpose." Thus, managers should incorporate in their decision-making process the implementation of appropriate instruments for the management of risks that may influence the supply chain negatively [50,51].

As we can conclude, the disruption of the value chain of companies in Guinea-Bissau caused by the COVID-19 pandemic was detected at the beginning of the pandemic through publicly disclosed information, and companies generally did not have metrics to measure the impact of this disruption. In this way, the company's strategy to face the ruptures in the value chain was a reactive strategy, and, therefore, this rupture was not overcome by the introduction of technological, organizational and logistical innovations. In this way, Proposition 1 is confirmed.

Regarding the role of regulatory bodies in the supply of products to consumers, according to company A, the State of Guinea-Bissau has an important role, as mentioned by all the companies, because they are responsible for setting the price of raw materials that ultimately influence the supply chain of companies. This type of regulation is also a source of disruptive activity in supply chains $[39,40]$. However, Company B, C and D claim that Guinea-Bissau does not have regulatory bodies for the supply of products to consumers.

\subsection{Resilience in the Supply Chain}

Table 4 shows the results of the responses of the CEOs of the interviewed companies regarding supply chain resilience, i.e., the existence of business strategies to prepare for and respond to a supply chain crisis $[10,53,54]$.

Companies $\mathrm{A}, \mathrm{B}$ and $\mathrm{C}$ have strategies to prepare and respond to a situation of disruption in the supply chain: Company A has a specialized office to deal with crises and where action and communication strategies are developed to minimize its consequences; Company B uses horizontal communication strategies (within the company and the group of companies) and vertical (customers and suppliers), and Company C uses an operational strategy that consists of the annual purchase of raw materials, which mitigates the risk of disruption in the supply chain whenever a disruptive event occurs. Company D does not have a strategy prepared to respond to a disruption in the supply chain, implementing a reactive strategy in a crisis. As argued by Alonso-Muñoz et al. [9], communication and cooperation increase the resilience of supply chains in crises. 
Table 4. Resilience in the Supply Chain.

\begin{tabular}{|c|c|c|c|c|c|c|c|c|c|c|}
\hline Company & $\begin{array}{l}\text { Strategies for } \\
\text { Replying to } \\
\text { Disruptions }\end{array}$ & $\begin{array}{l}\text { Resources that } \\
\text { Sustain the } \\
\text { Disrupting } \\
\text { Event }\end{array}$ & $\begin{array}{c}\text { Consequence } \\
\text { of Strategies on } \\
\text { Disruption }\end{array}$ & $\begin{array}{l}\text { Competitive } \\
\text { Position of the } \\
\text { Firm }\end{array}$ & $\begin{array}{l}\text { Process of } \\
\text { Acquiring } \\
\text { Knowledge } \\
\text { from } \\
\text { Stakeholders }\end{array}$ & $\begin{array}{l}\text { Activities Exist } \\
\text { to Promote the } \\
\text { Sharing of } \\
\text { Information } \\
\text { between Other } \\
\text { Companies }\end{array}$ & $\begin{array}{c}\text { Ability to } \\
\text { Obtain Product } \\
\text { over a } \\
\text { Disruptive } \\
\text { ActivityImpact } \\
\text { on Areas of the } \\
\text { Supply Chain }\end{array}$ & $\begin{array}{l}\text { Available } \\
\text { Suppliers }\end{array}$ & Obstacles & $\begin{array}{c}\text { How to Better } \\
\text { Prepare a } \\
\text { Supply Chain }\end{array}$ \\
\hline Company A & $\begin{array}{l}\text { The company has an } \\
\text { office specialized in } \\
\text { dealing with crises. }\end{array}$ & $\begin{array}{l}\text { Existence of a } \\
\text { crisis office. }\end{array}$ & $\begin{array}{l}\text { Positive. A } \\
\text { proper } \\
\text { communication } \\
\text { strategy allows } \\
\text { you to keep } \\
\text { customers } \\
\text { informed and } \\
\text { ensure that the } \\
\text { impact is as } \\
\text { small as } \\
\text { possible. }\end{array}$ & $\begin{array}{l}\text { It allows you to } \\
\text { have a proactive } \\
\text { rather than } \\
\text { reactive strategy. }\end{array}$ & AT & $\begin{array}{l}\text { Establishment of } \\
\text { relationships of } \\
\text { trust and } \\
\text { constant } \\
\text { communication } \\
\text { for the balance } \\
\text { of the } \\
\text { relationship } \\
\text { between the } \\
\text { parties. }\end{array}$ & $\begin{array}{l}\text { High } \\
\text { obtainability } \\
\text { due to the } \\
\text { existing } \\
\text { commercial } \\
\text { relationship. }\end{array}$ & Yes & $\begin{array}{l}\text { Obtaining the } \\
\text { desired quantity } \\
\text { and delays in } \\
\text { the delivery } \\
\text { time. }\end{array}$ & $\begin{array}{l}\text { Analysis of } \\
\text { suppliers, good } \\
\text { relations } \\
\text { between the } \\
\text { parties, constant } \\
\text { communication } \\
\text { and the } \\
\text { existence of a } \\
\text { crisis office. }\end{array}$ \\
\hline Company B & $\begin{array}{l}\text { Cohesion, immediate } \\
\text { and effective } \\
\text { communication at } \\
\text { vertical and horizontal } \\
\text { levels (between the } \\
\text { head office and } \\
\text { between other } \\
\text { companies), and } \\
\text { communication with } \\
\text { customers. }\end{array}$ & $\begin{array}{l}\text { Diversity of } \\
\text { investments; } \\
\text { prepared human } \\
\text { resources and } \\
\text { having access to } \\
\text { a diverse and } \\
\text { global network } \\
\text { and experiences. }\end{array}$ & $\begin{array}{l}\text { Positive. } \\
\text { Flexibility to } \\
\text { offer varied } \\
\text { services. }\end{array}$ & $\begin{array}{l}\text { Enables you to } \\
\text { have a proactive } \\
\text { rather than } \\
\text { reactive strategy. }\end{array}$ & $\begin{array}{l}\text { Regular internal } \\
\text { reports, } \\
\text { Customer } \\
\text { feedback } \\
\text { (evalua- } \\
\text { tion/satisfaction } \\
\text { forms). }\end{array}$ & $\begin{array}{c}\text { Easy } \\
\text { communication } \\
\text { with the } \\
\text { different } \\
\text { departments of } \\
\text { the company. }\end{array}$ & $\begin{array}{l}\text { Ability to adapt } \\
\text { to new services } \\
\text { and products } \\
\text { quickly, taking } \\
\text { into account the } \\
\text { flexibility of } \\
\text { operation given } \\
\text { the company. }\end{array}$ & Yes & $\begin{array}{c}\text { Lower quantity; } \\
\text { price increase, } \\
\text { and delivery } \\
\text { delays. }\end{array}$ & $\mathrm{AT}$ \\
\hline Company C & $\begin{array}{l}\text { Strategies at the } \\
\text { operational level: } \\
\text { annual purchases of } \\
\text { raw materials. }\end{array}$ & $\begin{array}{l}\text { Working capital } \\
\text { to withstand } \\
\text { periods of } \\
\text { disruption and } \\
\text { efficiency in } \\
\text { stock } \\
\text { management. }\end{array}$ & $\begin{array}{c}\text { Positive above } \\
\text { all in terms of } \\
\text { the permanent } \\
\text { updating of } \\
\text { stocks. }\end{array}$ & $\begin{array}{l}\text { Enables you to } \\
\text { have a proactive } \\
\text { rather than } \\
\text { reactive strategy. }\end{array}$ & $\begin{array}{l}\text { Market research } \\
\text { and marketing } \\
\text { strategies. }\end{array}$ & None & $\begin{array}{l}\text { Through the } \\
\text { Internet. }\end{array}$ & Yes & $\begin{array}{c}\text { Delays in } \\
\text { delivery and } \\
\text { lack of financing } \\
\text { by outside } \\
\text { capital (e.g., } \\
\text { banks). }\end{array}$ & $\mathrm{AT}$ \\
\hline Company D & $\begin{array}{l}\text { They have no specific } \\
\text { strategy. The strategy } \\
\text { is reactive to the crisis. }\end{array}$ & $\begin{array}{l}\text { Material and } \\
\text { human } \\
\text { resources. }\end{array}$ & $\begin{array}{c}\text { Positive. It } \\
\text { allows to always } \\
\text { satisfy } \\
\text { customers due } \\
\text { to the existing } \\
\text { stocks. }\end{array}$ & No & $\begin{array}{l}\text { Through the } \\
\text { accounting } \\
\text { documents. }\end{array}$ & None & $\begin{array}{l}\text { Suppliers with } \\
\text { greater supply } \\
\text { capacity. }\end{array}$ & $\begin{array}{l}\text { Hardly. } \\
\text { Most are } \\
\text { by pre- } \\
\text { orders. }\end{array}$ & Delivery delays. & $\mathrm{AT}$ \\
\hline
\end{tabular}


In terms of resources that facilitate the reaction to a situation of disruption in the supply chain, company A refers to the existence of a crisis office that defines the strategies to protect themselves from a disruptive situation, i.e., this office builds a routine for nonroutine situations, being one of the main critical aspects of the supply chain's resilience [78]. Company B mentions the fact that the diversity of investments allows the company to sustainably survive a crisis in the supply chain because, as they own several businesses, they are usually not affected with the same intensity [58,79], additionally because the human resources trained and prepared for these situations and because it is an international company facilitating access to a network and diverse global experiences [80]. Company C mentions that financial resources, namely that it has working capital, facilitate the reaction to a crisis. Company C claims that "we have a financial cushion, to withstand a disruptive event for a month or two. We are also efficient in keeping stocks". Company D notes that it has material and human resources prepared for the best management of supply chain interruptions. The fact that the interviewed companies have resources to face interruptions in the supply chain positively affects the impact of these interruptions at the company level. This positive impact is translated into the disclosure of updated and permanent information to customers [80] so that there is no breach of trust (Company A), in the flexibility to offer alternative services and adjust to the customers' needs (Company B) as predicted by Juttner et al. [58], in the permanent updating of the stock level (Company C) and the constant satisfaction of the customers' needs (Company D). Thus, proposition 2, "In Guinea-Bissau, being an underdeveloped country, the value chain has low resilience to face disruptive situations.", is not confirmed.

Companies adopt strategies in advance to respond to and mitigate situations of supply chain interruption as it happens; with companies A, B and C, they are adopting proactive strategies, i.e., anticipating crises, and as such, they end up having competitive advantages over their competitors [19]. Company B also states that "the company has the flexibility to offer a variety of services, and therefore, if an area is affected, the company can present a new service to the market that is more in demand. In the case of file management, it allows for an easy adaptation of the services offered to the new needs of customers." However, as in company D, adopting a reactive strategy (reaction after a crisis) prevents the company from having a competitive advantage since its actions will always be later than those that adopt proactive strategies.

Information about stakeholders is important for supply chain management [81], and its sources are diverse: management reports of the company's departments, customer feedback through service satisfaction evaluation forms (Company B), market and marketing research (Company C) and accounting documents (Company D). The activities that promote sharing information between companies are also important, namely the constant (Company A) and regular (Company B) communication. Company A also states that "we are based essentially on establishing a relationship of trust". Companies C and D did not identify any information-sharing activities. Regarding the prior preparation of the supply chain for disruptive situations, only Company A mentioned that a good analysis of suppliers and a good relationship with stakeholders mitigates the consequences of a crisis. This finding is in line with what is indicated by Campos et al. [82], and Messina et al. [83].

Regarding the ability to obtain products when there is a disruption in the supply chain, companies A, B, and C refer that it is easy to obtain them because there are suppliers readily available due to their resilient role in the supply chain [84]. Company B further states that "in addition to the main suppliers at the group level, the company is free to buy raw material from local/regional suppliers". Although there are several obstacles (delivery delays, higher prices, lower than desirable quantity and lack of financing), Company D reports that it is difficult because it requires large quantities of raw materials that are hardly available from suppliers without prior orders. The supplier's resilience capability negatively affects the buyer's performance during disruptive events [85].

We can conclude that the fact that companies in Guinea-Bissau have vulnerable value chains and are very susceptible to disruptions due to their dependence on external markets 
means that business models are not based on a complex resilient adaptive system and, therefore, are not adapted in case of disruptive situations, confirming proposition 3.

\section{Conclusions}

This paper aims to analyze the effect of resilience on the supply chain of Guinea-Bissau (an underdeveloped country) during the COVID-19 pandemic, that is, in a disruptive situation or crisis, using the CAS theory that involves a complex network of agents, autonomous actions, interaction and learning. Two research questions were asked: (1) What is the impact of the constraints caused by the COVID-19 pandemic on the value chain of companies in Guinea-Bissau? (2) Could it be that companies that have larger, more resilient value chains have a greater capacity to respond and adapt to this disruptive situation?

Concerning the first research question, the COVID-19 pandemic negatively affected the functioning of supply chains, causing many disruptions to organizational operations due to a lack of supply and mobility issues that prevented normal functioning for a long period. In underdeveloped countries, the value chain has low resilience to face disruptive situations. Companies needed to be resilient and adapt to turbulent environments. These consequences were even more acute in underdeveloped countries, such as Guinea-Bissau, where almost nothing is produced domestically, and there is a heavy dependence on raw materials and final products abroad. The closure of borders to the outside and the transport difficulties caused serious disruptions in companies' supply chains. On the other hand, concerning the role of regulatory bodies in supplying products to consumers, 3 of the companies under study (B, C, D) state that Guinea-Bissau does not have regulatory bodies.

Regarding the second research question, the results show that, because companies in Guinea-Bissau are SMEs, most supply chains are small and informal, and there is a lack of preparation of supply chains for crises, i.e., they are more susceptible to the severe impacts of a disruptive situation. Even more, the disruption in the value chain of companies in Guinea-Bissau caused by the COVID-19 pandemic, as it is an underdeveloped country, has not been overcome by the introduction of technological, organizational and logistical innovations. This disruptive situation is more serious for companies the longer it lasts, the less quickly they are able to understand the reasons and sources of disruption, the lack of metrics to measure and react to disruptive events and the difficulties in assessing the impact of the crisis on the various stages of the supply chain. On the other hand, the type of products and services offered by companies (such as concentration on a single type of product, perishable products, products with high dependence on raw materials) also amplify the consequences of disruptive activities and the existing relationship with suppliers and management decisions are very important in minimizing the consequences of supply chain disruption. However, the more resilient the companies' supply chain is, the lower the crisis' impacts. Furthermore, the resilience of the supply chain will be all the greater when companies adopt proactive strategies to face disruptive situations, namely through the diversification of products and services, constant and permanent sharing of information among stakeholders, alternative solutions and a good relationship with suppliers, among others, which allow the company to obtain a competitive advantage in a crisis despite the obstacles of the negative context that the company is experiencing. The business model of companies in Guinea-Bissau should be based on a complex and resilient adaptive system that would allow them to adapt in a sustainable way to disruptive situations.

Given these results, there are several practical implications. The results suggest that companies need to formalize their supply chain with standards, procedures and rules that describe planning in its entirety and are strategically followed by the company [86-88]. Then, companies should focus on product diversification rather than concentration, avoiding total dependence on a single supply chain $[89,90]$. The companies should equip themselves with a set of metrics at the level of management control to detect an early disruption in the supply chain [91,92]. Companies can also diversify supply chains (existence of alternative suppliers in the supply portfolio) [93,94]. On the other hand, whenever there is a high dependence on raw materials imported from third countries, there should be a 
more effective and efficient stock management policy and alternative supply routes $[93,94]$. Finally, the decision centers of companies should develop proactive strategies to anticipate the consequences of disruptive crises in the supply chain $[95,96]$.

At the level of theoretical implications, this study contributes to the literature due to the scarcity of studies on supply chains in companies operating in African territories and, even mores, in crises such as the pandemic COVID-19. On the other hand, this study analyzes four companies trying to adapt their supply chains to the disruptions caused by the pandemic, i.e., the resilience of their supply chains was assessed in a country in which supply chains were significantly affected by the closure of borders as a result of their dependence on foreigners.

Regarding the limitations of the study, we highlight the difficulty of obtaining interviews with managers of companies in Guinea-Bissau, especially large companies and companies in the most significant sectors of activity in the legal economy of Guinea-Bissau (agricultural and fisheries). On the other hand, the informality of the supply chains made it difficult for the interviewees to perceive them. Moreover, using technical terminology in the interview made it difficult and limited the interviewees' answers. On the other hand, as we used a quantitative methodology, with interviews with managers from four companies, the results cannot be generalized and should be analyzed within the context of the identified crisis (COVID-19 pandemic). Future studies could expand the number and diversify the companies interviewed in terms of activity sector and size (micro, small, medium and large companies), identify supply chain resilience metrics and explore other supply chain resilience practices by different companies operating in Africa. It would be interesting to quantitatively assess, through the business reports of the interviewed companies, the impact of the COVID-19 pandemic on the value chain in order to assess its impact on the disruption of the value chain, as well as to determine which indicators of vulnerability and resilience of the value chains of companies in underdeveloped countries are relevant. Other qualitative studies should also be carried out to verify the role of Guinea-Bissau's regulatory bodies in the supply of products to consumers, as the results of this study indicate that they do not exist.

Author Contributions: Conceptualization, J.M.L. and S.G. methodology, J.M.L. and S.G.; software, J.M.L. and S.G.; validation, J.M.L., S.G. and L.M.; formal analysis, J.M.L. and S.G.; investigation, J.M.L., S.G. and L.M.; resources, J.M.L., S.G. and L.M.; data curation, S.G.; writing-original draft preparation, J.M.L., S.G. and L.M.; writing-review and editing, J.M.L., S.G. and L.M.; visualization, J.M.L., S.G. and L.M.; supervision, J.M.L.; project administration, J.M.L. All authors have read and agreed to the published version of the manuscript.

Funding: NECE-UBI: Research Centre for Business Sciences, Research Centre and this work are funded by FCT-Fundação para a Ciência e a Tecnologia, IP, project UIDB/04630/2020.

Institutional Review Board Statement: The study was conducted according to the guidelines of the Declaration of Helsinki and approved by the Institutional Review Board.

Informed Consent Statement: Informed consent was obtained from all subjects involved in the study.

Data Availability Statement: Not applicable.

Acknowledgments: The authors would like to thank the participants of the interviews.

Conflicts of Interest: The authors declare no conflict of interest.

\section{References}

1. Massari, G.F.; Giannoccaro, I. Investigating the effect of horizontal coopetition on supply chain resilience in complex and turbulent environments. Int. J. Prod. Econ. 2021, 237, 108150. [CrossRef]

2. Sawik, T. Integrated selection of suppliers and scheduling of customer orders in the presence of supply chain disruption risks. Int. J. Prod. Res. 2013, 51, 7006-7022. [CrossRef]

3. Mandal, S. An Empirical Investigation into Supply Chain Resilience. IUP J. Supply Chain. Manag. 2012, 9, 46-61.

4. Sodhi, M.S.; Son, B.-G.; Tang, C.S. Researchers' Perspectives on Supply Chain Risk Management. Prod. Oper. Manag. 2012, 21, 1-13. [CrossRef] 
5. Singhal, P.; Agarwal, G.; Mittal, M.L. Supply chain risk management: Review, classification and future research directions. Int. J. Bus. Sci. Appl. Manag. 2011, 6, 15-42.

6. Chen, J.; Sohal, A.S.; Prajogo, D.I. Supply chain operational risk mitigation: A collaborative approach. Int. J. Prod. Res. 2013, 51, 2186-2199. [CrossRef]

7. Gomes, S.; Sousa, M.; Santos, T.; Oliveira, J.; Oliveira, M.; Lopes, J.M. Opening the “Black Box" of University Entrepreneurial Intention in the Era of the COVID-19 Pandemic. Soc. Sci. 2021, 10, 181. [CrossRef]

8. Lopes, J.M.; Gomes, S.; Santos, T.; Oliveira, M.; Oliveira, J. Entrepreneurial Intention before and during COVID-19—A Case Study on Portuguese University Students. Educ. Sci. 2021, 11, 273. [CrossRef]

9. Alonso-Muñoz, S.; González-Sánchez, R.; Siligardi, C.; García-Muiña, F.E. New circular networks in resilient supply chains: An external capital perspective. Sustainbility 2021, 13, 6130. [CrossRef]

10. Ferreira, C.; Cardoso, C.; Travassos, M.; Paiva, M.; Pestana, M.; Lopes, J.M.; Oliveira, M. Disorders, Vulnerabilities and Resilience in the Supply Chain in Pandemic Times. Logistics 2021, 5, 48. [CrossRef]

11. Christopher, M.; Holweg, M. Supply chain 2.0 revisited: A framework for managing volatility-induced risk in the supply chain. Int. J. Phys. Distrib. Logist. Manag. 2017, 47, 2-17. [CrossRef]

12. Yaroson, E.V.; Breen, L.; Hou, J.; Sowter, J. Advancing the understanding of pharmaceutical supply chain resilience using complex adaptive system (CAS) theory. Supply Chain Manag. Int. J. 2021, 26, 323-340. [CrossRef]

13. Ryczyński, J.; Tubis, A.A. Tactical risk assessment method for resilient fuel supply chains for a military peacekeeping operation. Energies 2021, 14, 4679. [CrossRef]

14. Habibi Rad, M.; Mojtahedi, M.; Ostwald, M.J. The Integration of Lean and Resilience Paradigms: A Systematic Review Identifying Current and Future Research Directions. Sustainability 2021, 13, 8893. [CrossRef]

15. Zavala-Alcívar, A.; Verdecho, M.-J.; Alfaro-Saiz, J.-J. A Conceptual Framework to Manage Resilience and Increase Sustainability in the Supply Chain. Sustainability 2020, 12, 6300. [CrossRef]

16. Silva, R.M.d. Os impactos da pandemia do COVID-19 na cadeia de suprimentos e atividades logísticas. INOVAE-J. Eng. Archit. Technol. Innov. 2021, 9, 448-467.

17. Chopra, S.; Sodhi, M.S. Reducing the risk of supply chain disruptions. MIT Sloan Manag. Rev. 2014, 55, 73-80.

18. Clark, G. Understanding and reducing the risk of supply chain disruptions. J. Bus. Contin. Amp; Emerg. Plan. 2012, 6, 6-12.

19. Hendry, L.C.; Stevenson, M.; MacBryde, J.; Ball, P.; Sayed, M.; Liu, L. Local food supply chain resilience to constitutional change: The Brexit effect. Int. J. Oper. Prod. Manag. 2019, 39, 429-453. [CrossRef]

20. WPR. Poorest Countries in the World 2021. Available online: https://worldpopulationreview.com/country-rankings/poorestcountries-in-the-world (accessed on 26 November 2021).

21. World Bank. The World Bank in Guinea-Bissau. Available online: https://www.worldbank.org/en/country/guineabissau/ overview (accessed on 14 September 2020).

22. Carvalho, B.R.P.; Mendes, H. Cashew Chain Value in Guiné-Bissau: Challenges and Contributions for Food Security: A Case Study for Guiné-Bissau. Int. J. Food Syst. Dyn. 2016, 7, 1-13. [CrossRef]

23. Mendes, E. Fatores que Inibem o Desenvolvimento da Guiné-Bissau; Universidade de Coimbra: Coimbra, Portugal, 2020.

24. AICEP. Mercado Guiné-Bissau. Available online: https://myaicep.portugalexporta.pt/mercados-internacionais/gw/ (accessed on 23 December 2021).

25. Khanal, P.; Bento, F.; Tagliabue, M. A Scoping Review of Organizational Responses to the COVID-19 Pandemic in Schools: A Complex Systems Perspective. Educ. Sci. 2021, 11, 115. [CrossRef]

26. Schiffling, S.; Hannibal, C.; Tickle, M.; Fan, Y.Y. The implications of complexity for humanitarian logistics: A complex adaptive systems perspective. Ann. Oper. Res. 2020, 1-32. [CrossRef]

27. Anderson, P. Complexity theory and organization science. Organ. Sci. 1999, 10, 216-232. [CrossRef]

28. Novak, D.C.; Wu, Z.H.; Dooley, K.J. Whose resilience matters? Addressing issues of scale in supply chain resilience. J. Bus. Logist. 2021, 42, 323-335. [CrossRef]

29. Preiser, R. Identifying general trends and patterns in complex systems research: An overview of theoretical and practical implications. Syst. Res. Behav. Sci. 2019, 36, 706-714. [CrossRef]

30. Preiser, R.; Biggs, R.; De Vos, A.; Folke, C. Social-ecological systems as complex adaptive systems: Organizing principles for advancing research methods and approaches. Ecol. Soc. 2018, 23, 46. [CrossRef]

31. Dentoni, D.; Pinkse, J.; Lubberink, R. Linking Sustainable Business Models to Socio-Ecological Resilience Through Cross-Sector Partnerships: A Complex Adaptive Systems View. Bus. Soc. 2021, 60, 1216-1252. [CrossRef]

32. Choi, T.Y.; Dooley, K.J.; Rungtusanatham, M. Supply networks and complex adaptive systems: Control versus emergence. J. Oper Manag. 2001, 19, 351-366. [CrossRef]

33. Pathak, S.D.; Day, J.M.; Nair, A.; Sawaya, W.J.; Kristal, M.M. Complexity and adaptivity in supply networks: Building supply network theory using a complex adaptive systems perspective. Decis. Sci. 2007, 38, 547-580. [CrossRef]

34. Tukamuhabwa, B.R.; Stevenson, M.; Busby, J.; Zorzini, M. Supply chain resilience: Definition, review and theoretical foundations for further study. Int. J. Prod. Res. 2015, 53, 5592-5623. [CrossRef]

35. Erengüç, Ş.S.; Simpson, N.C.; Vakharia, A.J. Integrated production/distribution planning in supply chains: An invited review. Eur. J. Oper. Res. 1999, 115, 219-236. [CrossRef] 
36. Xu, X.; Zhu, D.; Yang, X.; Wang, S.; Qi, L.; Dou, W. Concurrent practical byzantine fault tolerance for integration of blockchain and supply chain. ACM Trans. Internet Technol. (TOIT) 2021, 21, 1-17. [CrossRef]

37. Zhu, G.; Chou, M.C.; Tsai, C.W. Lessons Learned from the COVID-19 Pandemic Exposing the Shortcomings of Current Supply Chain Operations: A Long-Term Prescriptive Offering. Sustainability 2020, 12, 5858. [CrossRef]

38. Berger, P.D.; Gerstenfeld, A.; Zeng, A.Z. How many suppliers are best? A decision-analysis approach. Omega-Int. J. Manag. Sci. 2004, 32, 9-15. [CrossRef]

39. Bode, C.; Wagner, S.M. Structural drivers of upstream supply chain complexity and the frequency of supply chain disruptions. J. Oper. Manag. 2015, 36, 215-228. [CrossRef]

40. Wagner, S.M.; Bode, C. An Empirical Examination of Supply Chain Performance Along Several Dimensions of Risk. J. Bus. Logist. 2008, 29, 307-325. [CrossRef]

41. Zhu, Q.; Krikke, H.; Caniëls, M.C.J. The Effects of Different Supply Chain Integration Strategies on Disruption Recovery: A System Dynamics Study on the Cheese Industry. Logistics 2021, 5, 19. [CrossRef]

42. Klumpp, M.; Loske, D. Sustainability and Resilience Revisited: Impact of Information Technology Disruptions on Empirical Retail Logistics Efficiency. Sustainability 2021, 13, 5650. [CrossRef]

43. Pettit, T.J.; Croxton, K.L.; Fiksel, J. Ensuring Supply Chain Resilience: Development and Implementation of an Assessment Tool. J. Bus. Logist. 2013, 34, 46-76. [CrossRef]

44. Kondo, A. The effects of supply chain disruptions caused by the Great East Japan Earthquake on workers. Jpn. World Econ. 2018, 47, 40-50. [CrossRef]

45. Fartaj, S.-R.; Kabir, G.; Eghujovbo, V.; Ali, S.M.; Paul, S.K. Modeling transportation disruptions in the supply chain of automotive parts manufacturing company. Int. J. Prod. Econ. 2020, 222, 107511. [CrossRef]

46. Beltagui, A.; Rosli, A.; Candi, M. Exaptation in a digital innovation ecosystem: The disruptive impacts of 3D printing. Res. Policy 2020, 49, 1-48. [CrossRef]

47. Oliveira, M.; Santos, T.C.S.d.M.d.; Sousa, M.; Lopes, J.M. COVID 19 impacts on digital marketing strategies: The case of catering SMEs in Portugal. Acad. Entrep. J. 2021, 27, 1-9.

48. Oliveira, M.; Gomes, S.; Santos, T.C.S.d.M.d.; Oliveira, J.; Lopes, J.L. Alterations in consumers behaviour on food purchase during COVID-19 pandemic. Acad. Strateg. Manag. J. 2021, 1-9.

49. Carvalho, H.; Barroso, A.P.; Machado, V.H.; Azevedo, S.; Cruz-Machado, V. Supply chain redesign for resilience using simulation. Comput. Ind. Eng. 2012, 62, 329-341. [CrossRef]

50. Tang, C.S. Perspectives in supply chain risk management. Int. J. Prod. Econ. 2006, 103, 451-488. [CrossRef]

51. Tang, C.S. Robust strategies for mitigating supply chain disruptions. Int. J. Logist. Res. Appl. 2006, 9, 33-45. [CrossRef]

52. Benedito, E.; Martínez-Costa, C.; Rubio, S. Introducing Risk Considerations into the Supply Chain Network Design. Processes 2020, 8, 743. [CrossRef]

53. Sharma, H.B.; Vanapalli, K.R.; Cheela, V.S.; Ranjan, V.P.; Jaglan, A.K.; Dubey, B.; Goel, S.; Bhattacharya, J. Challenges, opportunities, and innovations for effective solid waste management during and post COVID-19 pandemic. Resour. Conserv. Recycl. 2020, 162, 105052. [CrossRef] [PubMed]

54. Singh, S.; Kumar, R.; Panchal, R.; Tiwari, M.K. Impact of COVID-19 on logistics systems and disruptions in food supply chain. Int. J. Prod. Res. 2021, 59, 1993-2008. [CrossRef]

55. Pettit, T.J.; Fiksel, J.; Croxton, K.L. Ensuring Supply Chain Resilience: Development of a Conceptual Framework. J. Bus. Logist. 2010, 31, 1-31. [CrossRef]

56. Ponomarov, S.Y.; Holcomb, M.C. Understanding the concept of supply chain resilience. Int. J. Logist. Manag. 2009, 20, 124-143. [CrossRef]

57. Pavlou, S.; Manthou, V. Identifying and evaluating unexpected events as sources of supply chain risk. Int. J. Serv. Oper. Manag. 2008, 4, 604-617. [CrossRef]

58. Juttner, U.; Maklan, S. Supply chain resilience in the global financial crisis: An empirical study. Supply Chain Manag. Int. J. 2011, 16, 246-259. [CrossRef]

59. Souza, V.; Bloemhof-Ruwaard, J.; Borsato, M. Towards Regenerative Supply Networks: A design framework proposal. J. Clean Prod. 2019, 221, 145-156. [CrossRef]

60. Belhadi, A.; Kamble, S.; Jabbour, C.J.C.; Gunasekaran, A.; Ndubisi, N.O.; Venkatesh, M. Manufacturing and service supply chain resilience to the COVID-19 outbreak: Lessons learned from the automobile and airline industries. Technol. Forecast. Soc. Change 2021, 163, 120447. [CrossRef]

61. Elleuch, H.; Dafaoui, E.; Elmhamedi, A.; Chabchoub, H. Resilience and Vulnerability in Supply Chain: Literature review. IFAC-Pap. 2016, 49, 1448-1453. [CrossRef]

62. Marchi, J.J.; Erdmann, R.H.; Rodriguez, C.M.T. Understanding supply networks from complex adaptive systems. BAR-Braz. Adm. Rev. 2014, 11, 441-454. [CrossRef]

63. Giunipero, L.; Handfield, R.B.; Eltantawy, R. Supply management's evolution: Key skill sets for the supply manager of the future. Int. J. Oper. Prod. Manag. 2006, 26, 822-844. [CrossRef]

64. Flynn, B.B.; Flynn, E.J. Synergies between supply chain management and quality management: Emerging implications. Int. J. Prod. Res. 2005, 43, 3421-3436. [CrossRef] 
65. Heckmann, I.; Comes, T.; Nickel, S. A critical review on supply chain risk - Definition, measure and modeling. Omega-Int. J. Manag. Sci. 2015, 52, 119-132. [CrossRef]

66. Linnenluecke, M.K. Resilience in Business and Management Research: A Review of Influential Publications and a Research Agenda. Int. J. Manag. Rev. 2017, 19, 4-30. [CrossRef]

67. Afuah, A.; Tucci, C.L. Internet Business Models and Strategies: Text and Cases; McGraw-Hill: New York, NY, USA, 2003; Volume 2, p. 384.

68. Benbunan-Fich, R. Internet business models and strategies: Text and cases. Mid-Atl. J. Bus. 2000, 36, 229.

69. Itami, H.; Nishino, K. Killing Two Birds with One Stone: Profit for Now and Learning for the Future. Long Range Plan. 2010, 43, 364-369. [CrossRef]

70. Njie, B.; Asimiran, S. Case study as a choice in qualitative methodology. J. Res. Method Educ. 2014, 4, 35-40. [CrossRef]

71. Lopes, J.; Farinha, L.; Ferreira, J.J.; Ferreira, F. Peeking beyond the wall: Analysing university technology transfer and commercialisation processes. Int. J. Technol. Manag. 2018, 78, 107-132. [CrossRef]

72. Lopes, J.; Farinha, L.; Ferreira, J.J. Value Creation and Commercialization in Insular Ecosystems. Int. J. Soc. Ecol. Sustain. Dev. 2018, 9, 92-102. [CrossRef]

73. Rodrigues, I.M.F.M.; Soares, N.F.M.; Lopes, J.M.; Oliveira, J.C.; Lopes, J.M.N.G. Gamification as a new trend in the co-creation process. Rev. De Adm. Mackenzie 2021, 22. [CrossRef]

74. Barratt, M.; Choi, T.Y.; Li, M. Qualitative case studies in operations management: Trends, research outcomes, and future research implications. J. Oper. Manag. 2011, 29, 329-342. [CrossRef]

75. Yin, R.K. Qualitative Research from Start to Finish; Guilford Publications: New York, NY, USA, 2015.

76. Lopes, J.; Lussuamo, J. Barriers to University-Industry Cooperation in a Developing Region. J. Knowl. Econ. 2021, 12, 1019-1035. [CrossRef]

77. Yin, R.K. Case Study Research: Design and Methods; Sage Publications: Thousand Oaks, CA, USA, 2003.

78. Scholten, K.; Schilder, S. The role of collaboration in supply chain resilience. Supply Chain Manag. Int. J. 2015, 20, 471-484. [CrossRef]

79. Morcillo-Bellido, J.; Isasi-Sanchez, L.; Garcia-Gutierrez, I.; Duran-Heras, A. Model Based Analysis of Innovation in Sustainable Supply Chains. Sustainability 2021, 13, 4868. [CrossRef]

80. Wieland, A.; Marcus Wallenburg, C. The influence of relational competencies on supply chain resilience: A relational view. Int. J. Phys. Distrib. Logist. Manag. 2013, 43, 300-320. [CrossRef]

81. Tukamuhabwa, B.; Stevenson, M.; Busby, J. Supply chain resilience in a developing country context: A case study on the interconnectedness of threats, strategies and outcomes. Supply Chain Manag. Int. J. 2017, 22, 486-505. [CrossRef]

82. Campos, J.K.; Cardoso, P.c.A.; Callado, A.A.C.; Piecyk, M.I. CSR and Climate Change Implications for Multinational Enterprises. In The Potential Strategic Role of Logistics Service Providers in Extending Sustainability to the Supply Chain; McIntyre, J.R., Ivanaj, S., Ivanaj, V., Eds.; Edward Elgar Publishing: Cheltenham, UK, 2018; p. 368.

83. Messina, D.; Barros, A.C.; Soares, A.L.; Matopoulos, A. An information management approach for supply chain disruption recovery. Int. J. Logist. Manag. 2020, 31, 489-519. [CrossRef]

84. Ivanov, D. Revealing interfaces of supply chain resilience and sustainability: A simulation study. Int. J. Prod. Res. 2018, 56, 3507-3523. [CrossRef]

85. Durach, C.F.; Wiengarten, F.; Choi, T.Y. Supplier-supplier coopetition and supply chain disruption: First-tier supplier resilience in the tetradic context. Int. J. Oper. Prod. Manag. 2020, 40, 1041-1065. [CrossRef]

86. Ergen, E.; Akinci, B. Formalization of the Flow of Component-Related Information in Precast Concrete Supply Chains. J. Constr. Eng. Manag. 2008, 134, 112-121. [CrossRef]

87. Samuel, K.E.; Goury, M.-L.; Gunasekaran, A.; Spalanzani, A. Knowledge management in supply chain: An empirical study from France. J. Strateg. Inf. Syst. 2011, 20, 283-306. [CrossRef]

88. Autry, C.W. Formalization of reverse logistics programs: A strategy for managing liberalized returns. Ind. Mark. Manag. 2005, 34, 749-757. [CrossRef]

89. Macbeth, D.K.; Ferguson, N. Strategic Aspects of Supply Chain Management. Integr. Manuf. Syst. 1991, 2, 8-12. [CrossRef]

90. Martino, G.; Fera, M.; Iannone, R.; Miranda, S. Supply chain risk assessment in the fashion retail industry: An analytic network process approach. Int. J. Appl. Eng. Res. 2017, 12, 140-154.

91. Ambulkar, S.; Blackhurst, J.; Grawe, S. Firm's resilience to supply chain disruptions: Scale development and empirical examination. J. Oper. Manag. 2015, 33-34, 111-122. [CrossRef]

92. Namdar, J.; Torabi, S.A.; Sahebjamnia, N.; Nilkanth Pradhan, N. Business continuity-inspired resilient supply chain network design. Int. J. Prod. Res. 2021, 59, 1331-1367. [CrossRef]

93. Meyr, H.; Stadtler, H. Types of supply chains. In Supply Chain Management and Advanced Planning: Concepts, Models, Software and Case Studies, 3rd ed.; Springer: Heidelberg, Germany, 2005; pp. 65-80.

94. Asian, S.; Nie, X. Coordination in Supply Chains With Uncertain Demand and Disruption Risks: Existence, Analysis, and Insights. IEEE Trans. Syst. Man Cybern. Syst. 2014, 44, 1139-1154. [CrossRef] 
95. Yang, J.; Xie, H.; Yu, G.; Liu, M. Antecedents and consequences of supply chain risk management capabilities: An investigation in the post-coronavirus crisis. Int. J. Prod. Res. 2021, 59, 1573-1585. [CrossRef]

96. Grötsch, V.M.; Blome, C.; Schleper, M.C. Antecedents of proactive supply chain risk management - a contingency theory perspective. Int. J. Prod. Res. 2013, 51, 2842-2867. [CrossRef] 